\title{
PEMANFAATAN LIMBAH PATI ONGGOK DAN SEKAM PADI SEBAGAI BAHAN DASAR PANEL DINDING RINGAN YANG TANGGAP GEMPA
}

\begin{abstract}
Dini Pratiwi (06512086), Anindya Septiasti Tejowati (06512084), Muhammad Faisol Rusdiyanto (08512061), Kurniawan Jaya Sasmita(08512073), Titik Efianti (08512150)
\end{abstract}

Jurusan Arsitektur Fakultas Teknik Sipil dan Perencanaan Universitas Islam Indonesia

\begin{abstract}
One cause is shortage of housing in Indonesia is caused by the high. of construction to build a shelter and to minimize the high cost of construction is one of them is to use a cheaper alternative wall panel quality. In addition, Indonesia as a country that is vulnerable to earthquake shocks require earthquake responce of buildings in order to anticipate the existence of damage and casualties, In the article the results of this research, to create a lightweight wall panel including earthquake, the main material used is waste cassava starch and rice husk as filler and resin as matrix. The purpose of this article is to provide alternative building materials solution that responds to earthquake shocks so it can be recommended as a wall panel including earthquake. The method used in the process of research is pure research method in the laboratory while the analysis method is to use comparisons with the theories of reference. In the process of material research, done byfinding the exact composition of resin, fiber starch, caśsava and cassava pellets to obtain good mechanical characteristics. Results of laboratory tests showed that the composite panels on specific compositions have high mechanical characteristics.
\end{abstract}

Keywords: resins, waste cassava starch, rice husks, mechanical characteristics, earthquakeresponce. 


\section{PENDAHULUAN}

Tiap tahun pasokan rumah yang tersedia di Indonesia berkisar antara 150.000 unit. Dari jumlah tersebut masih terdapat kekurangan akan hunian sebanyak 290.000 unit dari kebutuhan rumah di Indonesia sebesar $\pm 1,1$ juta unit (Simanungkalit, 2004). Banyaknya kebutuhan akan rumah dipengaruhi oleh berbagai faktor, diantaranya yaitu pertambahan jumlah penduduk, bencana alam (gempa bumi, kebakaran, dan lain-lain) dan kebakaran. Salah satu penyebab kebutuhan akan rumah tinggal sulit untuk dipenuhi yaitu mahalnya biaya konstruksi untuk membangun suatu hunian. Hal tersebut dipengaruhi oleh tidak adanya standar operation procedure dan manual konstruksi, kompetensi mandor dan tukang yang beragam, standar ukuran satuan material yang berbeda - beda. Untuk meminimalisir tingginya biaya konstruksi tersebut adalah dengan menggunakan panel dinding alternatif yang berkualitas dan juga memiliki harga yang relatif murah (REI DIY, 2004).

Kepulauan Indonesia yang terletak di atas pertemuan lempeng Australia, lempeng Eurasia dan lempeng Pasifik menyebabkan kawasan tersebut rentan terhadap guncangan gempa bumi (wikipedia, 2006). Sebagian besar bangunan yang rusak oleh gempa bumi adalah bangunan dengan mutu rendah (Mustafa, 2000) dan bangunan dengan sistem konstruksi yang bersifat non engineered structures ${ }^{1}$ (Sarwidi, 2001). Untuk mengurangi banyaknya korban jiwa dan mengurangi kerusakan yang terjadi akibat gempa bumi adalah dengan mendirikan bangunan yang tanggap gempa (Tanaka, 2000; Sarwidi, 2003).

Dalam proses produksi pati onggok tiap harinya dibutuhkan sebanyak 70 100 ton pohon aren. Jumlah tersebut mampu menghasilkan limbah pati onggok sebanyak 20-50 ton per hari (Sugiyanto, 2009). Jumlah yang cukup besar tersebut telah mencemari sungaisungai yang berada di sekitar area produksi tersebut. Banyaknya limbah pati onggok pada kawasan sungai tersebut berdampak negatif yaitu menimbulkan bau yang tidak sedap dan mengurangi luas dari sungai itu sendiri (Kedaulatan Rakyat, 9 Februari 2009).

Pemanfaatan limbah sekam dikalangan masyarakat kurang optimal. Produk sampingan dari penggilingan padi tersebut memiliki prosentase cukup besar. Menurut data dari Badan Penelitian dan Pengembangan Pertanian, Departemen Pertanian, menyebutkan bahwa dari proses penggilingan padi biasanya diperoleh sekam sekitar $20-30 \%$, dedak antara $8-12 \%$ dan beras giling antara $50-63,5 \%$ dari bobot awal gabah (BPPP Departemen Pertanian, 2006). Pemanfaatan sekam padi saat ini adalah sebagai bahan pembakar bata merah, pakan ternak atau dibuang begitu saja. Padahal proses penghancuran limbah secara 
alami membutuhkan waktu yang cukup lama, sehingga apabila limbah tersebut dibuang begitu saja tentu dapat mencemari lingkungan.

Hasil yang diharapkan adalah panel dinding ringan hasil pengolahan limbah pati onggok dan sekam padi. Selain memanfaatkan sumber daya lokal (local resources) yang ramah lingkungan (eco-friendly), penelitian ini diharapkan dapat memenuhi kebutuhan masyarakat akan hunian yang memiliki keamanan (safety) dan kenyamanan (comfort), serta bernilai ekonomis dan terjangkau oleh masyarakat di Indonesia pada tingkat menengah ke bawah.

\section{Rumusan Masalah}

Berdasarkan latar belakang tersebut, maka penelitian yang akan dilakukan adalah studi mengenai pemanfaatan limbah pati onggok dan sekam padi sebagai bahan alternatif dalam pembuatan panel dinding ringan yang memiliki karakteristik mekanik yang tinggi. Rumusan masalah yang akan dicarikan solusinya adalah bagaimana mencari komposisi yang tepat dari bahan alternatif panel dinding interior yang terdiri dari bahan limbah pati onggok dan sekam padi yang dikompositkan dengan resin. Adapun sub permasalahannya adalah :

1. Apakah campuran ke-tiga bahan tersebut mampu menghasilkan suatu campuran pembentuk panel dinding ringan?

2. Bagaimana pengaruh penambahan sekam padi dan limbah pati onggok terhadap keuletan panel dinding ?

3. Bagaimana pengaruh penambahan resin terhadap keuletan panel dinding?

4. Apakah campuran ke-tiga bahan tersebut mempunyai karakteristik mekanik (kuat tekan, kuat lentur) yang tinggi ?

\section{Tujuan Penelitian}

Tujuan utama penelitian ini adalah mencari komposisi yang tepat dari bahan alternatif panel dinding interior yang terdiri dari bahan limbah pati onggok dan sekam padi yang dikompositkan dengan resin.

1. Mengetahui karakteristik limbah pati onggok, sekam padi dan resin sebagai bahan alternative penyusun panel dinding ringan.

2. Mencari prosentase yang tepat dari limbah pati onggok dan sekam padi sebagai bahan dasar pembuatan panel dinding ringan.

3. Mencari prosentase yang tepat dari resin dalam pengaruhnya terhadap daya rekat.

4.Mengetahui kemampuan panel dinding ringan terhadap gaya tekan dan gaya lentur per satuan luas.

\section{Tinjauan Pustaka}

Penelitian yang telah dilakukan oleh peneliti lain sebelumnya, menjadi tolak ukur dalam penelitian pemanfaatan sekam padi, ampas tebu dan abu terbang batu bara (fly ash) sebagai 
panel dinding ringan yang tanggap gempa. Penelitian tersebut antara lain sebagai berikut :

Penelitian tentang Pemanfaatan Limbah Sekam Padi, Ampas Tebu dan Abu Terbang Batu Bara (Fly Ash) sebagai Panel Dinding Akustik Ringan yang Tanggap Gempa menunjukkan bahwa penambahan sekam padi dan ampas tebu memiliki pengaruh yang cukup signifikan terhadap berat jenis panel komposit. Panel dinding komposit yang memiliki massa jenis relatif ringan memiliki respon yang bagus terhadap guncangan gempa (Pratiwi dkk. 2009).

Referensi yang diambil dari penelitian ini adalah penggunaan material sekam padi sebagai bahan pengisi (filler) dapat membuat panel dinding memiliki massa yang relatif lebih ringan.

Penelitian tentang Pemanfaatan Anyaman Bilah Bambu Sebagai Pengganti Tulangan Besi Pada Dinding Beton, menunjukkan dinding beton dengan tulangan anyaman bilah bambu mampu berdiri menjadi dinding non structural, menambah nilai estetika pada dinding, tahan lama dan memiliki harga relatif lebih murah. Metode penelitian yang dipakai adalah menggunakan desain penelitian murni di laboratorium (true eksperimental research) (Pratiwi dkk. 2007).

Referensi terhadap penelitian ini bahwa metode penelitian yang dipakai adalah menggunakan desain penelitian murni di laboratorium (true eksperi- mental research).

Penelitian komposit penguat dari serat alam yang digunakan sebagai bahan bangunan untuk menggantikan serat sintetik berbasis fiber reinforced concrete (FRC), berhasil dilakukan. Hasil penelitian menunjukkan bahwa serat alam sangat potensial dijadikan sebagai bahan bangunan karena bersifat renewable ${ }^{2}$ dan biodegredable ${ }^{3}$ dalam pembangunan jangka panjang. (Komariah, 2007)

Referensi dari penelitian ini adalah teknik komposit penguat dari serat alam yang digunakan sebagai bahan bangunan untuk menggantikan serat sintetik berbasis fiber reinforced cocerete (FRC) karena bersifat renewable dan biodegradable.

Proses pembuatan dinding komposit berbasis FRC, mempunyai tiga tahapan. Pertama, persiapan matriks (semen PC dan aditif PVA/RE), persiapan reinforcement dan filler (ijuk dan sludge) ditimbang dengan berbagai variasi . Kedua, proses blending dimana matriks ,filler dan reinforcement dicampur dan diaduk hingga rata. Ketiga, proses pencetakkan dimana pasta komposit dimasukkan dalam cetakan , diratakan, ditutup dan diberi pembebanan kemudian pengerasan normal pada suhu kamar dan didiamkan selama 28 hari (Fairiyanto dan Firdaus, 2007).

Referensi dari penelitian ini adalah metedologi penelitian dalam proses pembliatan dinding komposit berbasis FRC yang mempunyai tiga tahapan : 
persiapan matriks, proses blending, proses pencetakan.

Penelitian tentang Penambahan Abu Sekam Pada Beton Dalam Mengantisipasi Kerusakan Akibat Magnesium Sulfat Pada Air Laut, menunjukkan bahwa setelah dilakukan perendaman selama 90 hari dilakukan uji kuat tekan beton. Hasilnya menunjukkan terjadi penurunan kuat tekan beton setelah direndam, penambahan abu sekam dapat meningkatkan kuat tekan beton atau dapat mengantisipasi kerusakan pada beton. Prosentase optimal dari penambahan abu sekam adalah $16,8 \%$ dari berat semen. Penambahan abu sekam juga mengurangi nilai slum (Putra, 2006).

Referensi yang diambil dari penelitian ini adalah penambahan abu sekam dapat meningkatkan kuat tekan beton atau dapat mengantisipasi kerusakan pada beton.

Panel dinding partisi dan plafon tahan air dari komposit sabut kelapa (coconut coir) dan sampah plastic (thermo plastic) berbasis fiber reinforced plastic (FRP) telah berhasil dilakukan. Hasil penelitian menunjukkan bahwa karakteristik mekanik prodok papan dan dinding partisi meningkat seiring dengan peningkatan komposisi kandungan matriksnya (sampah plastik) dalam persen berat (sampah plastik: sabut kelapa $=40: 60$, $50: 50 \%$ ). Rekayasa tekstur daan pewarnaan yang dilakukan menunjuk- kan hasil karena pruduk panel dinding partisi dan plafon yang dihasilkan memiliki flesibilitas tinggi untuk diberi. perlakuan tekstur dan warna secara variatif. Potensi besar ini akan menjadi solusi stratugis bagi persoalan lingkungan dan pemukiman dimasa mendatang. (Fajriyanto dan Firdaus, 2006)

Referensi dari penelitian ini adalah teknik penggunaan serat alam sebagai bahan pengisi panel dinding telah berhasil dilakukan.

\section{METODE PENELITIAN}

Metedeologi penelitian menggunakan metode penelitian eksperimen murni di laboratorium (true experimental research). Penelitian yang dilakukan adalah produksi panel dinding ringan tanggap gempa dari bahan baku komposit limbah pati onggok, sekam padi dan resin. Metode penelitiannya mengadopsi dan memodifikasi pada metode penelitian yang sudah dilakukan oleh Peneliti lainnya: Pratiwi, 2009; Pratiwi, 2008; Pratiwi, 2007 juga diadopsi dan dimodifikasi, seperti: Pramudyanto (2007), Komariah (2007), Fajriyanto dan Firdaus (2007), Putra (2006), Fajriyanto dan Firdaus (2006), Fajriyanto dan Firdaus (2005), Harsono (2002), Randing (1995). Metode dalam penelitian yang diadopsi dan dimodifikasi adalah berupa tahapan pelaksanaan yakni berupa tahapan persiapan matriks, biending (pencampuran), dan casting (pencetakan). 


\section{Tahap persiapan matriks}

Persiaan dari bahan baku utama yang diperlukan dalam penelitian adalah resin sebagai matriks (diperoleh dari toko kimia yang ada di Yogyakarta), limbah pati onggok sebagai reinforced dan filler (diperoleh dari Desa Daleman dan Pucungmiliran Kecamatan Tulung Kabupaten Klaten), limbah sekam padi sebagai filler (diperoleh dari petani lokal di Yogyakarta). Adapun peralatan yang diperlukan dalam penelitian adalah grander (perajang bahan baku), desikator, peralatan gelas dan bejana logam, dan blending, torsee (uji mekanik - dinamik) DAN UTM (Universal Testing Machine), standing wave tube, sine generator, measuring amplifier, heterodyne slave filter, dan standing wafe apparatus.

\section{Blending (pencampuran)}

Produksi panel komposit tersusun dari matriks (perekat) berupa resin dan hardener (katalis). Limbah pati onggok yang digunakan dibagi dalam dua jenis yang terdiri dari serat pati onggok dan butiran onggok. Serat pati onggok akan difungsikan sebagai reinforced (tulangan), sedangkan butiran pati onggok akan difungsikan sebagai filler (pengisi) bersama sekam padi.

Larutan resin sebagai matriks akan ditambahkan dengan katalis lalu dikompositkan dengan serat pati onggok sebagai reinforced, dan filler berupa sekam padi dan butiran onggok. Panel dinding komposit akan dibuat menggunakan sistem layer (berlapis) dimana pada lapisan pertama dan ketiga merupakan komposit antara serat pati onggok dan resin, sedangkan pada lapisan kedua merupakan komposit antara butiran onggok, sekam padi dan resin.

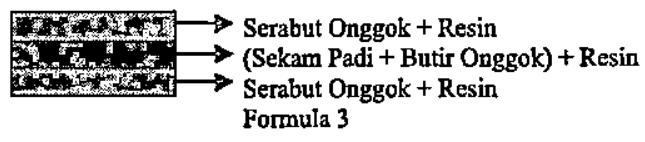

Gambar 1. Susunan Penyusun Panel Komposit

\section{Casting (pencetakan)}

Setelah dilakukan pencampuran, maka dimulai proses pencetakan dengan cetakan aluminium $19 \times 5 \times 6 \mathrm{~cm}^{3}$ yang kemudian ditekan menggunakan silinder beton $30 \mathrm{~kg}$. Benda uji tersebut dibuat dengan ukuran $19 \times 5 \times 6 \mathrm{~cm}^{3}$ yang disesuaikan dengan ukuran dalam pengujian karakteristik mekanik (kuat tekan dan kuat lentur) dan dalam ukuran berdiameter $9 \mathrm{~cm}$ dengan ketebalan $6 \mathrm{~cm}$, yang disesuaikan dengan ukuran yang dibutuhkan dalam pengujian kemampuan menyerap suara.

\section{Uji dan Analisis Karakteristik Mekanik}

Uji dan analisis karakteristik mekanik (kuat tekan dan kuat lentur) mengacu pada SNI 2003-1727-1989 mengenai Tata Cara Perencanaan Pembenbanan Untuk Bahan Bangunan Rumah dan Gedung. Pengujian dilakukan dengan memberi beban maksimal kepada benda uji, beban maksimal tersebut yang digunakan untuk menghitung kuat 
tekan dan kuat lentur dari panel dinding komposit. Total benda yang diuji yaitu sebanyak 20 buah dengan ukuran $19 \times 6 \times 5 \mathrm{~cm}^{3}$.

\section{HASIL DAN PEMBAHASAN}

Pengaruh Pengurangan Resin Terhadap Kelayakan Uji Mekanik dan Daya Rekat

Tabel 2. Formula Panel Dinding Komposit dan Hasil Uji Visual

\begin{tabular}{|c|c|c|c|c|c|}
\hline & $\begin{array}{c}\mathrm{SP}^{2}: \\
\mathrm{BO}^{3} \\
50: \\
50\end{array}$ & $\begin{array}{c}\text { SP: } \\
\text { BO } \\
40: \\
60\end{array}$ & $\begin{array}{c}\text { SP: } \\
\text { BO } \\
30: \\
70\end{array}$ & $\begin{array}{l}\text { SP: } \\
\text { BO } \\
20: \\
80\end{array}$ & $\begin{array}{l}\text { SP: } \\
\text { BO } \\
10: \\
90\end{array}$ \\
\hline $\begin{array}{c}\mathrm{SO}^{1}: \\
\text { Resin } \\
1: \\
0,9\end{array}$ & A1 & A2 & A3 & A4 & A5 \\
\hline $\begin{array}{c}\text { SO : } \\
\text { Resin } \\
1: \\
0,8\end{array}$ & B1 & B2 & B3 & B4 & B5 \\
\hline $\begin{array}{c}\text { SO : } \\
\text { Resin } \\
1: \\
0,7\end{array}$ & c1 & C2 & c3 & C4 & C5 \\
\hline $\begin{array}{c}\text { SO: } \\
\text { Resin } \\
1: \\
0,6\end{array}$ & D1 & D2 & D3 & D4 & D5 \\
\hline $\begin{array}{c}\text { SO : } \\
\text { Resin } \\
1: \\
0,5\end{array}$ & E1 & $E 2$ & E3 & E4 & E5 \\
\hline $\begin{array}{c}\text { SO: } \\
\text { Resin } \\
1: \\
0,4\end{array}$ & $F_{1}$ & $F 2$ & $F 3$ & $F 4$ & $F 5$ \\
\hline $\begin{array}{c}\text { SO : } \\
\text { Resin } \\
1: \\
0,3\end{array}$ & G1 & G2 & G3 & G4. & G5 \\
\hline $\begin{array}{c}\text { So: } \\
\text { Resin } \\
1: \\
0,2\end{array}$ & $H 1$ & $H 2$ & H3 & $\mathrm{H4}$ & H5 \\
\hline
\end{tabular}

Proses produksi panel komposit 'SO : serabut pati onggok ${ }^{2} \mathrm{SP}$ : sekam padi
${ }^{3} \mathrm{BO}$ : butiran onggok

Bold : sampel layak uji

Italic : sampel tidak layak uji

yang meliputi proses preparasi bahan, proses penakaran bahan dengab gelas takar, proses pencampuran dan proses pencetakan bahan selanjutnya menghasilkan empat puluh sampel yang kemudian dilakukan uji visual guna mengetahui komposisi yang layak untuk diuji mekanik. Dari uji visual tersebut diketahui bahwa sampel A hingga $D$ layak untuk dilakukan uji mekanik dan sampel $E$ hingga $H$ tidak layak untuk diuji mekanik karena mengalami kerusakan yaitu tidak merekatnya bahan dan adanya cacat bentuk pada sampel. Dari hasil uji visual tersebut diketahui bahwa dengan adanya pengurangan resin mengakibatkan tidak merekatnya bahan dan cacat bentuk yaitu sampai pada sampel D1 - D5 dengan komposisi serabut onggok dibanding resin sama dengan $1: 0,6$.

Hasil Pengujian Karakteristik Mekanik (Kuat Tekan dan Kuat Lentur)

\begin{tabular}{|l|c|c|c|c|c|}
\hline & A1 & A2 & A3 & A4 & A5 \\
\hline $\begin{array}{l}\text { Kuat } \\
\text { Tekan } \\
\text { Kg/cm }\end{array}$ & 16,52 & 16,74 & $\begin{array}{c}21,2 \\
5\end{array}$ & 22,48 & 5,42 \\
\hline $\begin{array}{l}\text { Kuat } \\
\text { Lentur } \\
\text { Kg/cm }\end{array}$ & $\begin{array}{c}156,9 \\
8\end{array}$ & $\begin{array}{c}159,0 \\
2\end{array}$ & $\begin{array}{c}201, \\
83\end{array}$ & $\begin{array}{c}213,5 \\
6\end{array}$ & 77,22 \\
\hline
\end{tabular}

Tabel 3. Hasil Uji Tekan dan Kuat Lentur Sampel A1 hingga A5

Analisis Kuat Tekan dan Kuat Lentur Sampel A 
Pada pengujian karakteristik kuat tekan pada sampel A1 hingga sampel A5 menunjukan adanya kenaikan yang signifikan nilai uji kuat tekan dari sampel $A 1$ hingga A5 yang dapat disimpulkan bahwa sampai pada perbandingan sekam padi dan butir onggok sebanyak 20 : 80 maka akan tercapai nilai maksimum dari kuat tekan.

Hasil uji kuat lentur sampel A1 hingga A5 menunjukan perbandingan yang lurus dengan hasil uji kuat tekan yaitu mencapai nilai maksimun pada sampel A4 dengan perbandingan sekam padi dan butir onggok sebanyak $20: 80$.

Tabel 4. Hasil Uji Tekan dan Kuat Lentur Sampel B1 hingga B5

\begin{tabular}{|l|c|c|c|c|c|}
\hline & B1 & B2 & B3 & B4 & B5 \\
\hline Kuat & 20,92 & 22,96 & 26,9 & 28,70 & 15,5 \\
Tekan & & & 3 & & 6 \\
Kg/cm & & & & & \\
\hline Kuat & 198,7 & 218,14 & 255, & 272,68 & 147, \\
Lentur & 8 & & 86 & & 81 \\
Kg/cm $^{2}$ & & & & & \\
\hline
\end{tabular}

Analisis Kuat Tekan dan Kuat Lentur Sampel $B$

Pada hasil uji tekan sampel $B 1$ hingga B5 yang terdiri dari komposisi serabut onggok dibanding resin sebesar $100 \%$ : $80 \%$ menunjukan kenaikan nilai uji maksimum sampai pada sampel B5, butirhal ini sejalan dengan hasil uji mekanik pada sampel A1 hingga A5.:

Hasil uji kuat lentur sample B1hingga B5 menunjukkan perbandingan yang lurus dengan hasil uji kuat tekan yaitu mencapai nilai maksimum pada sampel B4 dengan perbandingan sekam padi dan butir onggok sebanyak $20: 80$.

Tabel 5. Hasil Uji Tekan dan Kuat Lentur Sampel $\mathrm{C} 1$ hingga $\mathrm{C5}$

\begin{tabular}{|l|c|c|c|c|c|}
\hline & $\mathrm{C} 1$ & $\mathrm{C} 2$ & $\mathrm{c} 3$ & $\mathrm{C} 4$ & $\mathrm{C5}$ \\
\hline Kuat & 25,22 & 17,70 & 14,4 & 5,58 & 11,37 \\
Teka & & & 9 & & \\
$\mathrm{n}$ & & & & & \\
Kg/c & & & & & \\
$\mathrm{m}^{2}$ & & & & & \\
\hline Kuat & 239,55 & 168,2 & 137, & 79,51 & 162,0 \\
Lent & & 0 & 61 & & 8 \\
ur & & & & & \\
Kg/c & & & & & \\
$\mathrm{m}^{2}$ & & & & & \\
\hline
\end{tabular}

Analisis Kuat Tekan Kuat Lentur Sampel C

Berbeda dengan kedua hasil uji pada sampel $A$ dan $B$, pada hasil uji $C$ yaitu sampel $\mathrm{C} 1$ hingga $\mathrm{C} 5$ menunjukan bahwa nilai kuat tekan terbesar berada di sampel $\mathrm{C} 1$ dan terkecil pada sampel C4 kemudian mengalami kenaikan nilai uji lagi pada sampel C5. $\mathrm{Hal}$ ini berarti dengan perbandingan serabut onggok dan resin sebesar 100 $: 70$, maka nilai kuat tekan yang paling maksimum berada pada perbandingan sekam padi dibanding butir onggok sebesar $50: 50$. Pada hasil uji kuat lentur pada sampel $\mathrm{C} 1$ hingga $\mathrm{C} 5$ berbanding lurus dengan hasil uji tekannya, yaitu terbesar pada sampel $\mathbf{C} 1$ kemudian mengalami penurunan hingga sampel $\mathrm{C} 4$ kemudian naik kembali pada sampel C5. 
Tabel 6. Hasil Uji Tekan dan Kuat Lentur Sampel D1 hingga D5

\begin{tabular}{|l|c|c|c|c|c|}
\hline & D1 & D2 & D3 & D4 & D5 \\
\hline $\begin{array}{l}\text { Kuat Tekan } \\
\text { Kg/cm }\end{array}$ & 16,63 & 21,14 & 19,3 & 27, & 5,4 \\
& & & 1 & 36 & 7 \\
\hline Kuat L entur & 158,0 & 200,8 & 183, & 259 & 77, \\
Kg/cm² & 0 & 2 & 49 &, 94 & 98 \\
\hline
\end{tabular}

Analisis Kuat Tekan dan Kuat Lentur Sampel $D$

Hasil uji tekan pada sampel D1 hingga D5 berbanding lurus dengan hasil uji tekan dan kuat lentur pada sampel $A 1$ hingga $A 5$ dan $B 1$ hingga B5 yaitu mengalami kenaikan yang signifikan dari sampel D1 hingga D4 kemudian turun pada sampel D5. Sama halnya dengan hasil kuat tekan, pada hasil uji kuat lentur pun mengalami kenaikan dari sampel D1 hingga D4 dan mengalami penurunan pada sampel D5.

Hasil uji mekanik pada semua sampel pada tabel-tabel diatas menunjukan bahwa diantara keseluruhan sampel tersebut terdapat empat sampel yang merupakan sampel terkuat terhadap tekan dan lentur, yaitu sampel B4.

\section{KESIMPULAN DAN SARAN}

Dari hasil penelitian dan analisis yang telah dilakukan diperoleh kesimpulan sebagai berikut :

1) Perbedaan kadar resin pada setiap step sampel mempengaruhi karakter mekanik dari sampel panel komposit tersebut. Dengan berkurangnya kadar resin pada panel komposit menyebabkan kekuatan tekan dan tarik menjadi bertambah namun hanya pada perbandingan serabut onggok dan resin sebesar $100: 60$ kemudian mengalami penurunan.

2)Penambahan butir onggok dan pengurangan jumlah sekam padi pada komposisi layer 2. secara dominan membuat panel komposit memiliki kemampuan kuat tekan dan kuat lentur menjadi lebih besar.

3) Komposisi panel komposit B4 merupakan komposisi yang paling baik dalam kemampuan mekaniknya karena nilainya yang paling tinggi.

Adapun rekomendasi yang diberikan adalah:

1. Untuk harga panel komposit yang dihitung sesuai dengan produksi laboratorium dapat berkurang apabila panel komposit diproduksi dalam jumlah yang besar atau secara fabrikasi.

2. Perlu diadakan penelitian lebih lanjut untuk memaksimalkan potensi penggunaan limbah pati onggok dan sekam padi sebagai filler pada panel komposit.

\section{DAFTAR PUSTAKA}

Simanungkalit P. 2004. Prospek dan Kendala Bisnis Properti di Indonesia, Prosiding Seminar Nasional Prospek dan Kendala Bisnis Properti di Indonesia: Magister Teknik Sipil UII, 15 Juni 2004. 
Litbang DPD REY DIY. 2004. Biaya Pembangunan Rumah Tinggal Dengan Berbagai Variasi Tipe Rumah (Rumah Sederhana, Rumah Menengah dan Rumah Mewah): Hasil Survey Dan Penelitian Litbang DPD REY DIY. Wikipedia.2006.http://id.wiki pedia.org/ Wiki/Gem pa_b u m i Yogyakarta_Mei_2006-49k-.html. Mustafa, A. 2000. Mutu Bangunan yang Rendah Rawan terhadap Bencana Gempa, Diskusi dan Konferensi Pers Hasil Observasi Gempa Pandeglang 2000: LP UII dan CEEDEDS UII Yogyakarta, 10 November 2000. Sarwidi. 2001. Lesson from Failure Non-Engineered Structures Damaged by Recent Earthquakes in Indonesia, International Workshop: IUDMP ITB-JICA-AARGI, Bali, Oktober 2001.

Tanaka, 1. 2000. Reduction of Preventable Death and Injuries, Lokakarya Nasional Bangunan Rumah Tinggal Sederhana Tahan Gempa: Evaluasi, Rekomendasi dan Sosialisasi: Jurusan Teknik Sipil UII-LP UII \& CEEDEEDS, Yogyakarta, 6 September 2000.

Sarwidi. 2003. Sebuah Tinjauan Aspek Konstruksi: Hunian yang Layak di Wilayah Rawan Gempa, Seminar Nasional Prospek Pembangunan Perumahan dalam Rangka Otonomi Daerah: Jurusan Arsitektur UII-DPD REY DIY, Yogyakarta, 4 Oktober 2003.
BPPP. 2006. Sekam Padi Sebagai Sumber Energi Alternatif dalam Rumah Tangga Petani: Departemen Pertanian.

Pratiwi, D., Nabila S., Ari J. 2009. Pemanfaatan Limbah Sekam Padi, Ampas Tebu Dan Abu Terbang Batu Bara ( $F / y A s h$ ) Sebagai Panel Dinding Akustik Ringan Yang Tanggap Gempa: Laporan akhir Program Kreativitas Mahasiswa Penelitian 2009.

Pratiwi, D., Zerlinda C. S., Anindya S.T. 2007. Pemanfaatan Anyaman Bilah Bambu Sebagai Pengganti Tulangan Besi Pada Dinding Beton: Laporan Penelitian Laboratorium teknologi Bahan FTSP/Arsitektur UII Yogyakarta.

Komariyah. 2007. Pengolahan Limbah Lumpur Lapindo Sebagai Bahan Alternatif untuk Pembuatan Genteng: Puslit UII.

Putra D. 2006. PenambahanAbu Sekam Pada Beton Dalam Mengantisipasi Kerusakan Akibat Magnesium Sulfat Pada Air Laut: Jurnal limiah Teknik Sipil Vol 10, No. 2, Juli 2006. Fajriyanto dan Firdaus F. 2006. Komposit Sampah Plastik (thermoplastic) dan Sabut Kelapa (coco fiber) untuk Produksi Plafon Tahan Air (water proof) : Analisis Sifat Mekanik, Fisikokimiawi dan Ketahanan Airnya: Laporan Penelitian Dosen Muda Dikti/ Mendiknas. 
Pemanfaatan Limbah Pati-......--. Dini, Anindya, Faisol, Kurniawan, Titik

SNI 03-1727-1989. 1989. Tata Cara turnya tidak dihitung. Bangunan Perencanaan Pembebanan Untuk tersebut biasanya didirikan oleh Bahan Bangunan Rumah dan masyarakat umum, berupa rumah Gedung.

\section{Footnotes} tempat tinggal, rumah ibadah, bangunan sekolah dan bangunan rumah tradisional.(Munandar, 2001)

${ }^{1}$ Non engineered structures : rumah yang dibangun berdasarkan pengalaman praktis, kekuatan struk-

${ }^{2}$ Renewable adalah dapat diperbaharui ${ }^{3}$ Biodegradable adalah dapat diuraikan secara natural 